\title{
Salary Surveys Report Declines in Pulmonologist, Allergist and Nurse Incomes
}

The 2016 Medscape Physician Compensation Report relates that orthopedic surgeons and cardiologists earn on average the most of those physicians surveyed ( $\$ 443,000$ and $\$ 410,000$ annually) (1). Pulmonologists and critical care physicians fell in the middle of the spectrum of physician incomes $(\$ 281,000$ and $\$ 306,000$ respectively). Allergists were at the lower end $(\$ 205,000)$. Physicians in each category earned more or the same in 2016 than in 2015 except pulmonologists and allergists which were down compared to 2015 incomes of $\$ 296,000$ ( $\$ 15,000$ decline) and $\$ 243,000$ ( $\$ 38,000$ decline). As in years past, the survey is nonscientific. Physicians were asked to provide their annual compensation for patient care including salary, bonus, and profit sharing if employed, earnings after taxes, and deductible business expenses (but before income tax) if in private practice.

The reason for the decrease is unclear but self-employed physicians (i.e., private practice) earned substantially more than employed physicians $(\$ 64,000$ more for men, $\$ 44,000$ more for women) (1). If more pulmonary physicians are becoming employed, this could be one reason for the decline in income. In 2016, the Medscape survey reported $59 \%$ of men and $72 \%$ of women were employed (1).

Nurses also made less on average in 2016. Incomes decreased from $\$ 79,000$ annually for RNs in 2015 to $\$ 78,000$ in 2016 (2). LPNs had a more substantial decrease from $\$ 46,000$ to $\$ 43,000$. RN's not employed full time made the same hourly wage as those employed full time (\$37/hour) and LPNs not employed full time actually made more per hour than those employed full time (\$23 compared to $\$ 21 /$ hour). The two most common reasons that nurses gave for decreased income was switching jobs or working less overtime.

Richard A. Robbins, MD

Editor, SWJPCC

\section{References}

1. Peckham C. Medscape Physician Compensation Report 2016. Medscape. April 1, 2016. Available at:

http://www.medscape.com/features/slideshow/compensation/2016/public/over view\#page $=1$ (accessed 2/9/17).

2. Yox SB, Stokowski LA, McBride M, Berry E. Medscape RN/LPN Salary

Report 2016. Medscape. November 2, 2016. Available at:

http://www.medscape.com/features/slideshow/nurse-salary-report-

2016? src=WNL specrep nursesalary 170209 MSCPEDIT usmds\&uac=927

3DT\&implD=1286926\&faf=1\#page=1 (accessed 2/9/17). 